\title{
Erratum: Requirement for Notch1 signals at sequential early stages of intrathymic T cell development
}

Joanne B Tan, Ioana Visan, Julie S Yuan \& Cynthia J Guidos

Nature Immunology 6, 671-679 (2005).

On page 673, the second sentence of the legend to Figure 2 should begin "ETPs $\left(3 \times 10^{4}\right)$ or Lin- bone marrow cells $\left(2 \times 10^{4}\right)$ purified from B6.CD45.1 mice...."

\section{Erratum: Stimulation of the vagus nerve attenuates macrophage activation by activating the Jak2-STAT3 signaling pathway}

Wouter J de Jonge, Esmerij P van der Zanden, Frans O The, Maarten F Bijlsma, David J van Westerloo, Roelof J Bennink, Hans-Rudolf Berthoud, Satoshi Uematsu, Shizuo Akira, Rene M van den Wijngaard \& Guy E Boeckxstaens Nature Immunology 6, 844-851 (2005).

On page 845 , the last sentence should begin "The selective non- $\alpha 7 \mathrm{nAChR}$ antagonist dihydro- $\beta$-erythroidine...." On page 848 , in the legend for Figure 7, lines 15-16, the scale bar should be described as "Scale bar, $20 \mu \mathrm{m}$ ( $40 \mu \mathrm{m}$ for far left image)." 